\title{
ヒトデ類焼成物の食中毒菌発育阻止効果と キャラクタリゼーション
}

\author{
高間浩蔵* ·鈴木鐵也* ·加賀 壽** ・ 高村 巧** \\ 田谷嘉浩**.下野 功**・渡辺定嗣*
}

\begin{abstract}
Inhibition of the Growth of Foodborne Disease Causing Bacteria by Starfish Calcined Powders and Their Characterizations
\end{abstract}

\author{
TAKama Kozo*, Suzuki Tetsuya*, Kaga Hisashi**, TAKamura Takumi** \\ TAYA Yoshihiro**, Shimono Isao** and WATANABE Sadatsugu* \\ * Hokkaido University, Faculty of fisheries, \\ 3-1-1 Minato-cho, Hakodate 041-8611 \\ ** Hokkaido Industrial Technology Center, \\ 379 Kikyo-cho, Hakodate 041-0801
}

Delipidated and dehydrated starfish, Asteropecten scoparius, Asterias amurensis Asterina pectinifera and Distolasterias nippon were calcined and powered to test their bactericidal effects for foodborne disease causing bacteria. The powders calcined at $550^{\circ} \mathrm{C}$ showed merely inhibition for the growth of Escherichia coli O-157 : H7, Staphylococcus aureus and Salmonella enteritidis. However, the powders calcined at $700^{\circ} \mathrm{C}$ completely inhibited the bacterial growth at over $0.4 \%$ (minimal concentration tested). $\mathrm{CaCO}_{3}$, a major chemical constituent of the starfish, changed to $\mathrm{CaO}$ by calcination at $700^{\circ} \mathrm{C}$ or higher. The Asterias amurensis and Distolasterias nippon powders calcined at $900^{\circ} \mathrm{C}$ for $10 \mathrm{hrs}$ consisted of $\mathrm{Ca}, \mathrm{Mg}, \mathrm{Na}$ and $\mathrm{Cl}$, of $72 \sim 77,11 \sim 15,5.4 \sim 6.4$ and $2.9 \sim 4$. $3 \%$, respectively, as the major minerals. Even in $0.02 \%$ aqueous solution of the powders procured by calcination at $800^{\circ} \mathrm{C}$, the $\mathrm{pH}$ values indicated were around 11.5 , and $0.2 \%$ solution had about 12.5 of high alkalinities. From the results, it seems that the bactericidal effect of calcined powder of starfish could be attributed to the multiple effects of high alkalinity and other trace elements.

(Received Jul. 10 1998)

北海道沿岸域にはホタテ貝やホッキ貝などの二枚貝漁 場が広く展開している。このような漁場では, ヒトデが 二枚貝の天敵生物であることから，漁業者は多大な駆除 努力を余儀なくされている。駆除作業によって陸揚げさ れたヒトデ類の多くは土中に埋められるか，あるいは他 の加工廃裹物とともに焼却処分されている。すなわち,
効果的な利用法がないままに，場合によっては環境污染 の原因ともなりかねない状況にある。 本研究では, これらのヒトデ類の有効利用の一策とし て, $\mathrm{CaCO}_{3}$ に富む七トデ類外殼組織に注目し，焼成物 として食中毒菌発育阻止剂としての利用性を検討した。 また，焼成物の性状についても併わせて検討した。 


\section{実 験 方 法}

\section{1. 材料}

北海道余市町のホッキ貝漁場で捕獲されたモミジガイ (Asteropecten scoparius)，および北海道常呂町の木 夕テ貝漁場で陸揚げされたヒトデ (Asterias amurensis), イトマキヒトデ (Asterina pectinifera) およびニッポンヒトデ (Distolasterias nippon) を入手 し，実験に供するまでー $20^{\circ} \mathrm{C}$ に保管した。

\section{2. 焼成物の調製}

材料を解凍，細砕後，クロロホルムーメ夕ノール (2

：1）混液（モミジガイの場合のみ）またはアセトンで 脱脂した。脱脂物から気流中で溶剂除去し， $550^{\circ} \mathrm{C}$ また は $700^{\circ} \mathrm{C}$ (モミジガイでは約 $700^{\circ} \mathrm{C}$ で焼成）に温度設定 した電気マッフル炉でそれぞれ恒量化した。生成物を粉 砕して焼成粉末とし，以後の実験に供した。

\section{3 . 供試菌株と処理方法}

本研究では, 代表的な食中毒菌として, Escherichia coil O-157：H7 (北海道渡島保健所より分与), Staphylococcus aureus IFO-15035, およびSalmonella enteritidis IFO-3313を供試した。基本的な処理方法 は以下のようである。すなわち，4.5mlの蒸留水に所定 量の焼成粉末を懸濁させ， $121^{\circ} \mathrm{C}$ に設定のオートクレー ブで15分間滅菌した。室温まで放冷後, 予め用意して おいた約 $10^{4} \mathrm{cfu} / \mathrm{m} \ell の$ 菌液を $0.5 \mathrm{~m} \ell$ 加之た。所定時間の 接触の後, その $0.1 \mathrm{~m} \ell$ 規定の平板培地 $(E$. coliおよび S. aureusでは普通寒天培地，S . enteritidisでは MLCB培地）に塗抹し， $37^{\circ} \mathrm{C}$ ，24時間培養してコロニ 一数を測定した。

\section{4. 焼成粉末の性状}

脱脂細砕材料を $500^{\circ} \mathrm{C}$ から $900^{\circ} \mathrm{C}$ までの $100^{\circ} \mathrm{C}$ 間隔でそ れぞれ10時間加熱処理した。それらを乾式ボールミル

(10mm фアルミナボール) で24時間粉砕処理した。粉末 の平均粒度は, エチレングリコールを分散媒としてレー ザ回析式粒度分布測定装置（Malven社製 Master Sizer MS20型）によって測定した。また，焼成粉末の 構成成分は粉末 X 線回折装置（日本電子製JDX-8020 型）を用い，X線管にCuターゲット，管電圧 $40 \mathrm{kV}$, 管 電流 $25 \mathrm{~mA}$ の条件で分析した。ミネラル成分は蛍光 $\mathrm{X}$ 線 分析装置（島津製作所製 XRF-1700型）を用いて分 析した。すなわち，焼成粉末を $\phi 35 \mathrm{~mm} \times 4 \mathrm{~mm}$ の円盤状と L, X線管にRhターゲットを用いて管電圧 $40 \mathrm{kV}$, 管電 流70mAの条件で測定した。

\section{結果および考察}

\section{1. ヒトデ類焼成粉末の食中毒菌発育阻止効果}

モミジガイ脱脂細砕物を, 約 $700^{\circ} \mathrm{C}$ で焼成した粉末の 水懸濁液の食中毒菌の発育に及ぼす影響について検討し た結果，菌処理液中に $2.0 \%$ までの粉末添加，30分間の 接触試験において，0.16\%以上の添加で，いずれの試 験菌に対してもほぼ完全に発育を阻止した（デー夕は示 さない)。

また，菌体との接触時間は， $1.2 \%$ 懸濁液を用い $E$. coliに対して検討したところ，5分間で高い細菌発育阻 止効果が認められた（Fig. 1)。そこで，以後の実験に おいては菌体との接触時間を 5 分間とし，粉末添加濃度 は0.4\%から $2.0 \%$ 範囲で行った。

Table 1 に, $550^{\circ} \mathrm{C}$, および $700^{\circ} \mathrm{C}$ で焼成したヒトデ 類粉末懸濁液のE. coliの発育に及ぼす影響について示 してある。 $550^{\circ} \mathrm{C}$ 焼成物では，0.8\%以上の添加で明ら かな菌の発育阻止効果が見られたが，2.0\%添加でも完 全には阻止できなかった。しかし， $700^{\circ} \mathrm{C}$ 焼成物では試 験した最少量の $0.4 \%$ でもほぼ完全に菌の発育を抑制し た。

\section{2. 焼成粉末の性状}

ヒトデ脱脂細砕物の焼成に際し, 細菌発育阻止効果を 示すためには，その効果を高める条件として焼成温度が 大きく影響していることが予想された。そこで， $500^{\circ} \mathrm{C}$ から $100^{\circ} \mathrm{C}$ ずつの間隔で $900^{\circ} \mathrm{C}$ までの異なる温度でそれ

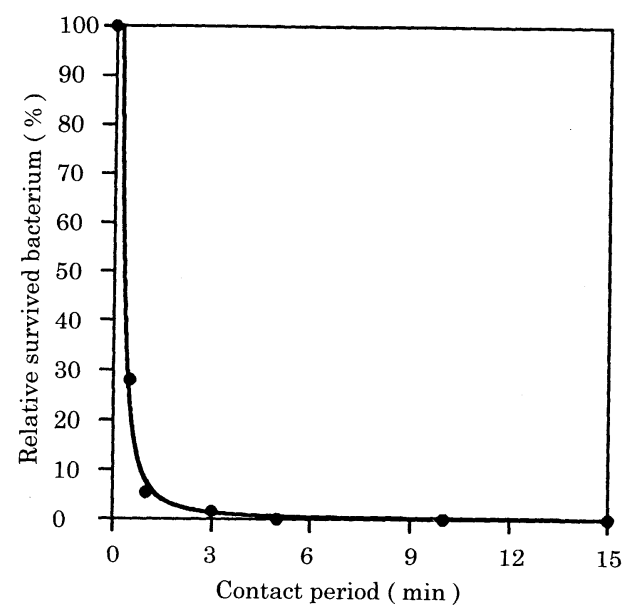

Fig. 1 Effect of contact period of aqueous solution of calcined powder on survival of bacteria Tested materials: 1.2\% solution of Asteropecten scoparius (Momijigai) powder Escherichia coli : ca. $10^{4} \mathrm{cfu} / \mathrm{m} \ell$ 
Table 1. Effect of the calcined powder prepared from starfish on the growth of Escherichia coli

\begin{tabular}{|c|c|c|c|c|c|c|}
\hline \multirow{4}{*}{$\begin{array}{l}\text { Concentration of } \\
\text { calcined powder } \\
(\%)\end{array}$} & \multicolumn{6}{|c|}{ Colony count* / plate } \\
\hline & \multicolumn{6}{|c|}{ Calcined temperatue } \\
\hline & \multicolumn{3}{|c|}{$550^{\circ} \mathrm{C}$} & \multicolumn{3}{|c|}{$700^{\circ} \mathrm{C}$} \\
\hline & Hitode $^{1)}$ & Itomaki2) & Nippon ${ }^{3)}$ & Hitode $^{1)}$ & Itomaki ${ }^{2)}$ & Nippon ${ }^{3)}$ \\
\hline 2.0 & 395 & 385 & 440 & ND & ND & ND \\
\hline 1.6 & 425 & 570 & 455 & ND & ND & ND \\
\hline 1.2 & 495 & 585 & 445 & 0 & 0 & 0 \\
\hline 0.8 & 485 & 610 & 500 & 0 & 0 & 0 \\
\hline 0.4 & 585 & 745 & 715 & 0 & 0 & 0 \\
\hline Control & 745 & 760 & 780 & 860 & 860 & 860 \\
\hline
\end{tabular}

1) Hitode (Asterias amurensis), 2) Itomaki hitode (Asterina pectinifera), 3) Nippon hitode (Distolasterias nippon) ND : not determined, *mean value of duplicate measurements
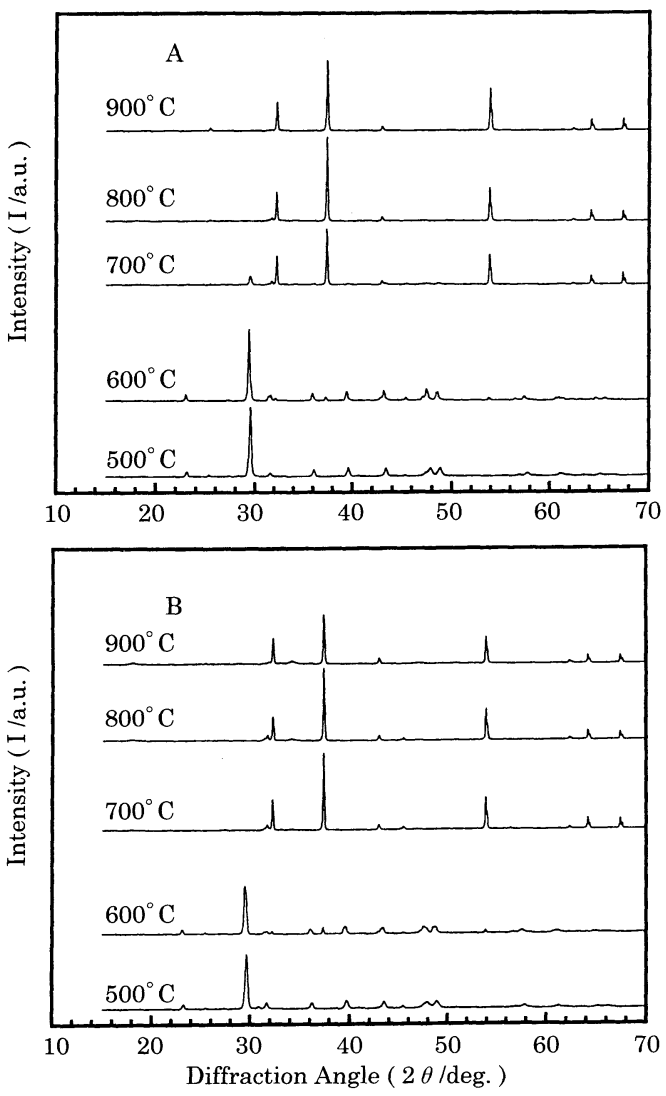

Fig. 2 Product in starfish powder depending on the calcination temperature

A: Hitode (Asterias amurensis), B: Nippon hitode (Distolasterias nippon), Calcination period: $10 \mathrm{hrs}$ at each indicated temperature
ぞれ10時間焼成処理して調製したヒトデおよびニッポ ンヒトデ粉末（平均粒度： $3 \sim 6 \mu \mathrm{m}$ ) を用い，粉末構 成成分と焼成温度の関係を検討した。結果をFig. 2 に 示す。

いずれのヒトデ類とも $600^{\circ} \mathrm{C}$ 加熱までは $\mathrm{CaCO}_{3}$ に帰属 するピークが認められた。しかし， $700^{\circ} \mathrm{C}$ 以上の加熱条 件ではCaOに基づくピークが認められこのことが細 菌発育阻止効果の発現と関連するものと判断された。な お， $900^{\circ} \mathrm{C} て ゙ 10$ 時間，加熱焼成した粉末をデシケー夕中

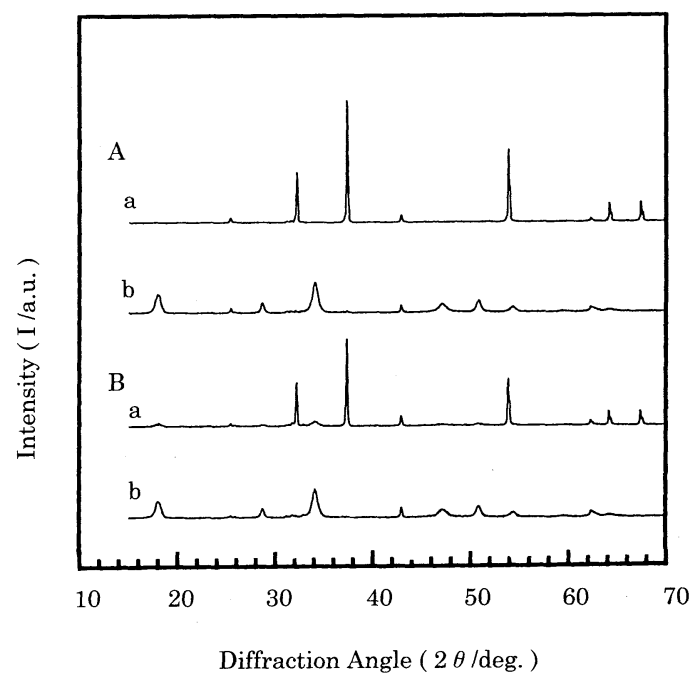

Fig. 3 Changes of product in calcined powder after standing for 1 month in a desiccator at room temperature

A: Hitode (Asterias amurensis), B: Nippon hitode (Distolasterias nippon), a: just after calcination at $900^{\circ} \mathrm{C}$ for $10 \mathrm{hrs}, \mathrm{b}: 1$ month later 
Table 2. Mineral composition of calcined powder prepared from starfish

\begin{tabular}{crrr|crcr}
\hline \multicolumn{3}{c|}{$\begin{array}{c}\text { Hitode } \\
\text { (Asterias }\end{array}$} & \multicolumn{4}{c}{$\begin{array}{c}\text { Nipurensis) } \\
\text { (Distolasterias }\end{array}$} & \multicolumn{2}{c}{ nippon) } \\
\hline $\mathrm{Ca}$ & 76.98 & $\mathrm{Mg}$ & 11.26 & $\mathrm{Ca}$ & 72.08 & $\mathrm{Mg}$ & 14.64 \\
$\mathrm{Na}$ & 5.36 & $\mathrm{Cl}$ & 2.90 & $\mathrm{Na}$ & 6.41 & $\mathrm{Cl}$ & 4.25 \\
$\mathrm{~K}$ & 0.97 & $\mathrm{~S}$ & 0.97 & $\mathrm{~K}$ & 0.71 & $\mathrm{~S}$ & 0.65 \\
$\mathrm{P}$ & 0.83 & $\mathrm{Sr}$ & 0.37 & $\mathrm{P}$ & 0.62 & $\mathrm{Sr}$ & 0.32 \\
$\mathrm{Fe}$ & 0.14 & $\mathrm{Si}$ & 0.10 & $\mathrm{Fe}$ & 0.14 & $\mathrm{Si}$ & 0.07 \\
$\mathrm{Cr}$ & 0.07 & $\mathrm{Zn}$ & 0.05 & $\mathrm{Cr}$ & 0.07 & $\mathrm{Zn}$ & 0.02 \\
$\mathrm{Al}$ & 0.01 & $\mathrm{Br}$ & 0.01 & $\mathrm{Al}$ & 0.01 & $\mathrm{Br}$ & 0.01 \\
\hline
\end{tabular}

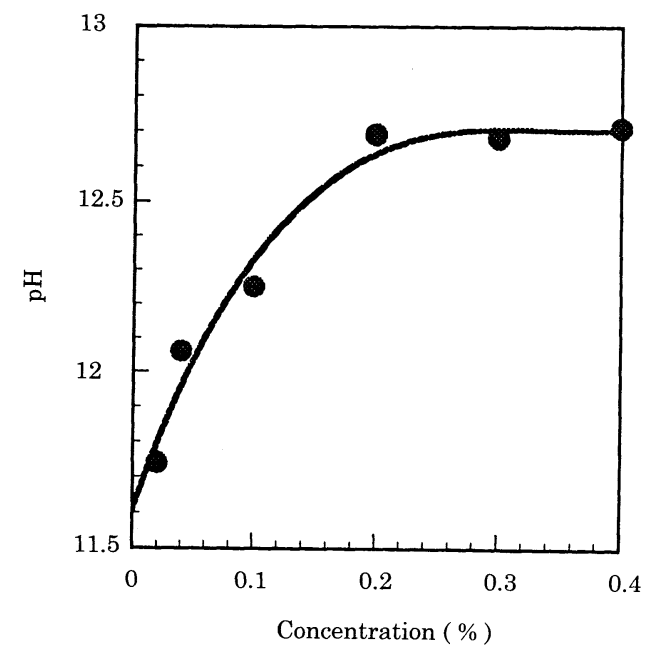

Fig. 4 Relationship between $\mathrm{pH}$ value and the concentration of calcined powder in an aqueous solution

で1 カ月間放置すると, $\mathrm{Ca}(\mathrm{OH})_{2}$ に変化していること も認められた（Fig. 3)。

蛍光 $\mathrm{X}$ 線分析法で測定した $700^{\circ} \mathrm{C} ， 10$ 時間焼成粉末の 元素組成をTable 2 に示す。ヒトデおよびニッポンヒト デとも $\mathrm{Ca}, \mathrm{Mg}, \mathrm{Na}, \mathrm{Cl}$ がそれ゙れ $72 〜 77,11 〜 15$, 5.4〜6.4，2.9〜 4.3\%を占める主要元素であった。

Fig. 4 に示すように, $800^{\circ} \mathrm{C}$ 焼成粉末の水溶液は $0.02 \%$ 濃度でも $\mathrm{pH}$ 值は約 11.5 を示し， $0.2 \%$ 以上の添 加溶液では約12.5を超える強アルカリ性であった。
このことから，本実験条件では，効果的な細菌発育阻 止作用の発現には，焼成粉末水溶液の $\mathrm{pH}$ 約 12.5 以上 に調整されていることが必要であるものと推察された。 一色ら ${ }^{1)}$ は，力キ凯を研磨して得られる内部の真珠層の みを通電ジュール加熱して約 320 メシュとした粉末を 用い微生物制御について詳細な検討を行い，このカルシ ウム製剂の抗菌作用は, 水酸化カルシウムと共存する微 量ミネラルとの複合的効果であろうとしている。本研究 におけるヒトデ焼成物の細菌発育阻止作用も基本的には カキ殸と同様の効果に基づくものであろう。

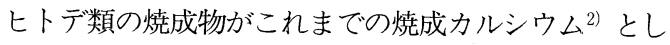
ての利用に加之て, 食品環境の微生物制御にも活用でき る可能性を示した。これらの産業廃亲物利用のためのよ り効率的焼成条件などに関し，さらに検討中である。

\section{要 約}

二枚貝漁場での天敵生物であるヒトデ類を活用する目 的で, 焼成粉末とし, 食中毒菌制御剂としての利用可能 性を検討した。モミジガイ (Asteropecten scoparius), ヒトデ (Asterias amurensis), イトマキヒトデ (Asterina pectinifera) およびニッポンヒトデ (Distolasterias nippon) のそれぞれを脱脂後, $700^{\circ} \mathrm{C}$ 前後で焼成した粉末の水溶液はEscherichia coli O-157: H7, Staphylococcus aureusおよびSalmonella enteritidis に対し，試験した最少濃度の $0.4 \%$ で完全に発育を抑制 した。 $550^{\circ} \mathrm{C}$ 前後で得られたものでは $2.0 \%$ の濃度でも 完全抑制は認められなかった。ヒトデ類では， $600^{\circ} \mathrm{C}$ 焼 成物は外殼組織成分の $\mathrm{CaCO}_{3}$ が主要成分であるが, $700^{\circ} \mathrm{C}$ 以上の焼成物はCaOであった。また， $\mathrm{Ca}, \mathrm{Mg}$ それぞれ72〜77，11～15\%からなる焼成カルシウムで あった。焼成粉末の水溶液は高アルカリ性を示すことか ら，共存する他の微量ミネラルなどの作用とともに，食 中毒菌に対する発育阻止作用を示したものと推察された。

\section{文 献}

1）一色賢司・栖原 浩 - 水内健二・德岡敬子：日食工 誌，42，135（1994）

2）食品・食品添加物等規格基準 (抄), III. 食品添加

物，食衛誌，39，J-88（1998）

$\left(\begin{array}{l}\text { 平成10年 } 7 \text { 月 } 10 \text { 日受付，平成10年 } 9 \text { 月 } 28 \text { 日受理 } \\ \text { Received Jun. 10, } 1998 \text {; Accepted Sep. 28, 1998 }\end{array}\right)$ 